\section{inimi ICESBA \\ Procedia of Economics \\ and Business Administration}

ISSN: 2392-8166, ISSN-L: 2392-8166
Available online at

$\underline{\text { www.icesba.eu }}$

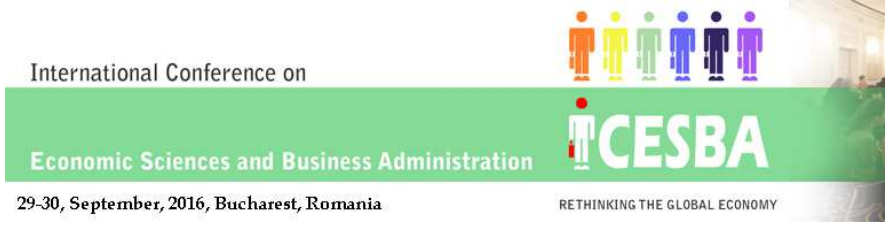

\title{
Renewable Energy and the Environment
}

\author{
Cornelia MARIN ${ }^{1}$, Liliana GURAN-NICA ${ }^{2}$ \\ ${ }^{1,2}$ Spiru Haret University, 13, Ion Ghica street, Bucharest, 030045, Romania \\ Tel: +40 0213112947, Fax: + 400213112947, Email: mrn cornelia@yahoo.com
}

\begin{abstract}
The rush for renewable energy, as an alternative to energy from fossil fuels, generates a number of problems. This paper proposes to investigate domestic energy production using waterfalls. The country has a tradition of harnessing water power by building hydroelectric crowned with success. To these were added in recent years, small hydropower plants (SHP)whose beneficiaries aim to tap the energy of mountain water courses. The amount of energy produced in the country, which has water source, covers about a third of necessary. Is it a renewable energy with minimal environmental impact? Amid legislation and especially of taxation that favors the construction of such SHPs the number of such projects has exploded, although at the same amount of electricity produced an SHP has a 5-8 times higher impact on biodiversity, compared to a hydroelectric dam with. The impact that these have on the environment (SHP) is underreported. We present in this paper how the intervention works in the minor bed for installing water abstraction and adduction results in reduced water flow rate, to change the morphological characteristics of the river beds, the impaired quality of surface waters, and not least to the deterioration of ecosystems of river beds. The case studies that will be presented will focus on SHP Capra in Fagaraș Mountains where deforestation were not the only danger, and SHP Nera, project that would be carried out in the vicinity of the protected area Nera and was provisionally blocked.
\end{abstract}

Keywords: renewable energy, environment, small hydropower plants

JEL classification:Q29

\section{Introduction}

Renewable energy refers to the energy which does not contribute to greenhouse effect emissions and implicitly to climate changes [2]. That is why it is also called clean or "green" energy, being considered as having an insignificant impact upon the environment.

\footnotetext{
${ }^{2}$ Spiru Haret University, 13, Ion Ghica street, Bucharest, 030045, Romania
} 
Renewable energy is the solution when conventional resources near depletion. Each country imposed the finding of solutions and investments in the field of "green" energy. But how "green" is this renewable energy? The technology its generation is based on is still quite a pollutant technology, environmentally unfriendly. The operating period of the devices is not satisfactorily long and the waste itself becomes a problem. Thus, the situation occurs when the "green" energy has a significant impact upon the environment. The study carried out refers to the erection and operation of micro hydropower plants. The economic advantages must be weighed well against the impact upon the environment. The requirements that must be met for a correct positioning of the micro hydropower plants, and particularly checking the observance of the technical report, are elements that must be taken into consideration for any new project in the field.

\section{About Renewable Energy}

\subsection{The need to obtain renewable energy based on the increase of energy consumption}

The energy rush is similar to the money rush (or gold rush until not so long ago). Both individual and industrial consumers are increasing their electricity demand. The increased energy demand also results in the increase of the electricity price, which can be traced in both the final cost of any product and service and domestic costs. Reducing energy consumption is not a solution considering that comfort has become a necessity for modern mankind.

That is why electricity and its generation are among the main concerns of every current human society. The generation of electricity went through several stages: from the use of energy resulted by the firing of fossil fuels to the energy generated by water and then to nuclear energy - considered "clean" forms of energy as opposed to the one resulted by

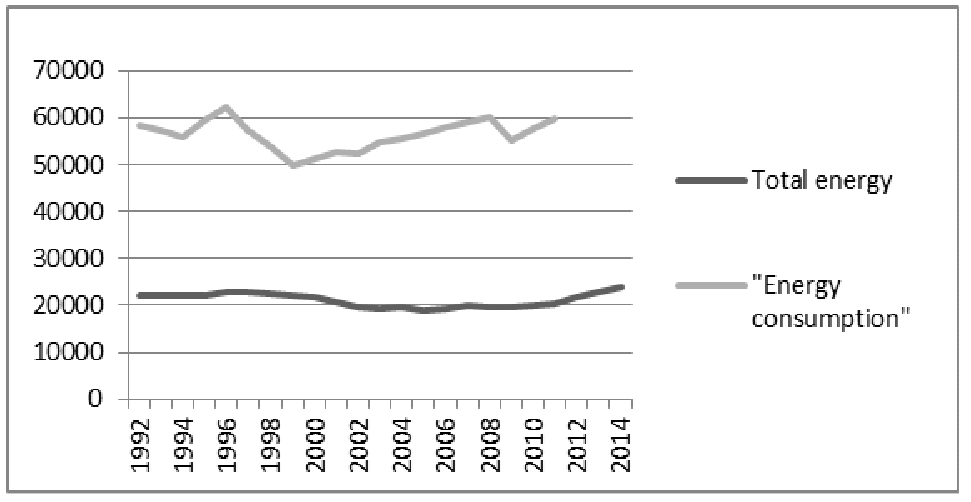

Figure 1. Total rated energy of electric generator sets according to categories of electric power plants and energy consumption in Romania, between 1992 and 2014 (source INSS) firing fossil fuels - and, more recently, renewable resources - wind power, geothermal energy, biomass, biogas (waste fermentation gas, sludge fermentation gas in the waste water treatment plants), solar energy. Traditional renewable energy, such as hydro-power, wind power, solar energy, biomass, diversified depending on local conditions and available technologi

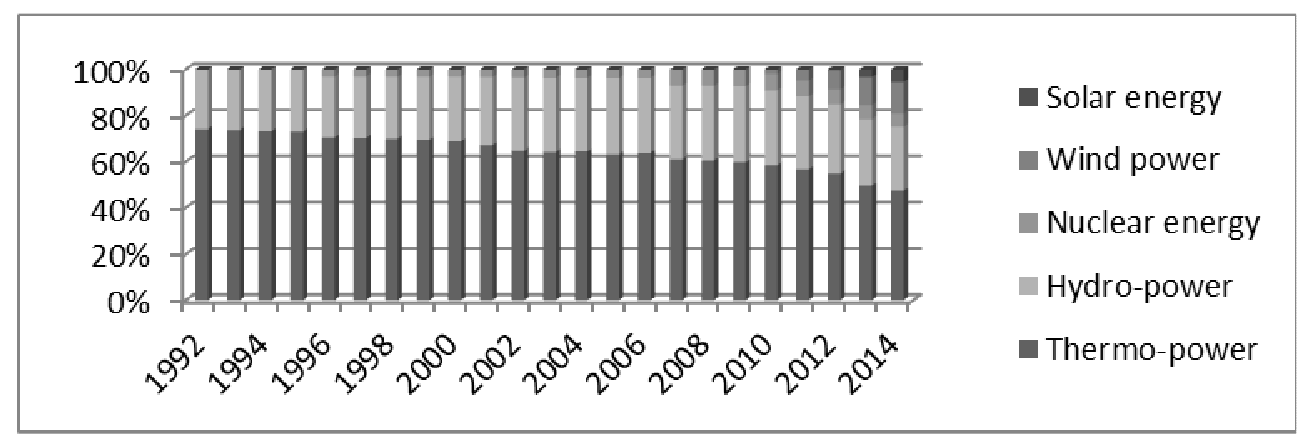

Figure 2 - Percentage distribution of energy generation sources between 1992 and 2014 (source INSS) 
es: geothermal energy, tidal energy, wave energy. An actual BANDWAGON effect was generated in the rush after "green" energy.

The total electric power generated in Romania between 1992 and 2014 can be seen in Figure 1, together with the evolution of the energy consumption over the same period. A decrease in the electric power requirement can be noticed between 1996 and 1999 as a result of closing down an important part of the energy-intensive industries. This economic conduct also required a decrease in the generation of electric power after 1999. The increase in the generation of electric power from renewable sources can be noticed beginning with 2010, based on the development of wind farms and solar parks (Fig. 2). The advantage of alternative energy sources is that they are practically inexhaustible (with reference herein to wind power and solar energy, but geothermal or biomass energy can also be added) and accessible on our level of access (according to the Russian physicist, we are a Type I civilization because we have access only to the energy accessible on our own planet and we aspire shyly to Type II civilization, that harnesses the energy radiated by its own star [6]).

Romania undertook before the European Commission that $24 \%$ of the total energy consumption in 2020 shall be from renewable sources. That was the target reached and exceeded from 2014, which caused a decrease of the investments in the field. In 2015, the green energy percent of the total energy consumption was $15.66 \%$ as opposed to only $1.29 \%$ in 2010 [4].

\subsection{How "green" renewable energy is}

Renewable energy gained the aura of a salvation for the future of the consumptionstarved humanity. The major issues raised by clean energy generation are related to the storage of such energy. The lack of efficient energy storage systems results in quite significant fluctuations in the generation of electric power. Photovoltaic power stations and wind farms generate energy during certain periods of a year, depending on the insolation level and wind power, respectively. Neither is the distribution within the territory of the country an even one, thus resulting in a concentration of solar parks in the southern and south-eastern part, and of wind farms in Dobrogea, in the central part of the Moldova Plateau, and some areas in Banat. In order to solve those shortcomings partially, the electricity transmission networks should be intelligent. But how clean this energy is, is a question asked more and more often.

In this study we focus only on a few sources of renewable energy.

If the position of the wind farms is analyzed, it may be noticed that the impact upon the environment commences right from the construction stage. The land taken by these wind turbines is quite large, including access roads to the wind turbines and the electricitygenerating installations. Once they become operational, the wind turbines shall maintain an impact upon the environment because they are more than often positioned on the flyway of migrating birds.

Specialty studies underlined that the second longest migration flyway in Europe (Via Pontica) passes through Dobrogea and the Danube Delta [3]. Several wind farms grouped together in a certain area may generate a change in migration flyways with a negative 
effect upon migrating birds (decrease of their body weight, loss of energy at a faster rate) [3].It was noticed that these constructions have a negative impact upon rodents (some would say "great", but the fact that the balance within the ecosystem is damaged must not be omitted), and may determine a disturbance of bird nesting areas. The fact that they change the landscape can be regarded as an advantage and not necessarily a negative fact. What is troublesome is the fact that a number of wind farms overlap / cross Natura 2000 sites (Fig. 3). In Tulcea County, it may be noticed that approximately one fourth of the wind turbines are located on protected sites.

But one of the significant problems generated by these wind turbines is represented by the high maintenance cost in addition to the initial costs with the equipment and installation. The study would not be complete if the social aspect related to the presence of these wind "farms" was not analyzed. Their construction lifted the hopes of the local communities (most of which were living in

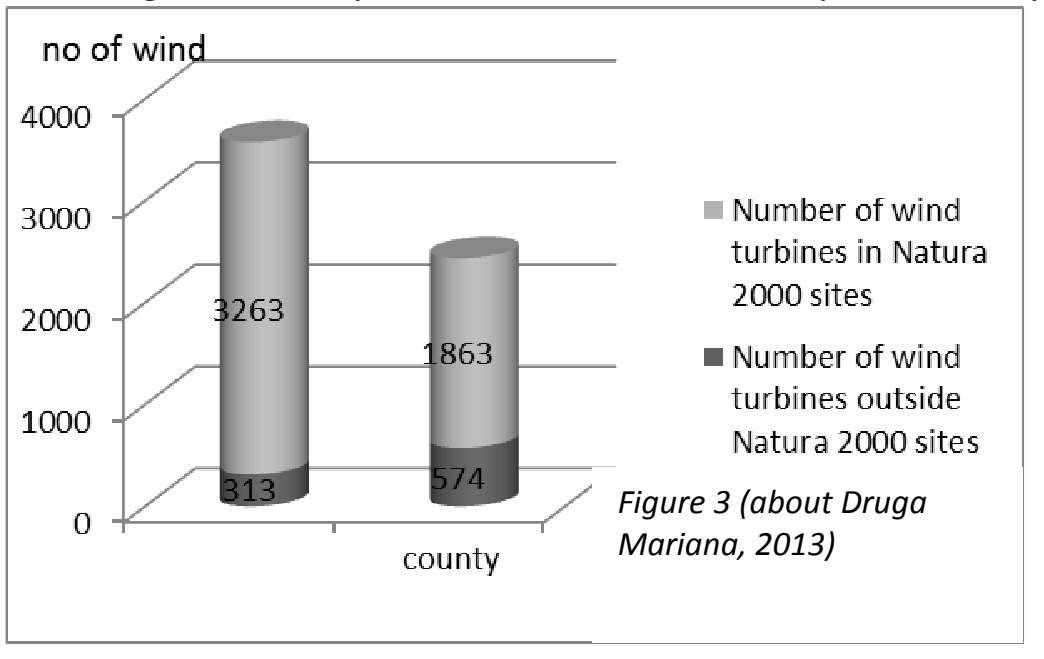
poverty) that they may benefit of electricity at a lower price, which would have led to a bearable financial effort. There are cases where the wind farms have been completed but never commissioned, as is the situation with the $27 \mathrm{MW}$ wind farm in Târgușor, Constanța County. Moreover, those who do not gain access to green certificates give up on supplying electricity [1].

A first condition for solar parks is arrangement. Photovoltaic arrays are efficient if they are exposed to sunlight for as many hours as possible. There is a direct connection between the quantity of generated electricity and the intensity of the light touching the surface of the panels. Besides photovoltaic panels, there are also solar thermal power stations, which operate by absorbing sunlight and the resulting heat transforms the water running a number of turbines into vapour. Such thermal power stations do not exist in our country. Photovoltaic parks have a number of advantages, such as easy arrangement, the fact that they generate electricity without noise-polluting the environment, the costs are lower than those for wind farms.

The disadvantages in using this source of generating electricity may be significant. The panels are manufactured using chemical solutions (such as sodium hydroxide and hydrofluoric acid). Moreover, both water and electricity are used (which involves the greenhouse gas emissions). If sunlight is renewable, photovoltaic panels are not. The solar panel manufacturing leaves behind waste and the lifespan of such panels is quite short (in the end becoming waste with an impact upon the environment), which makes "clean" electricity generation a difficult target to attain in this manner. Currently, the recycling of solar panels raises the following issues: There are not enough recycling locations for old 
solar panels, and there are not enough old solar panels to make recycling economically profitable.

Just like in the case of wind "farms", solar parks do not represent an economic advantage for the communities in their neighbourhood. The benefits cannot be found in the supply of energy at preferential prices, but in the investors' incomes who also gain the equivalent for the green certificates, which reward the generation of renewable energy, besides the price for the generated energy.

\subsection{Obtaining renewable energy using the power of water, in our country (tradition and current status)}

The power of water was used by the Romanian peasant from the ages of time. His resourcefulness led to using the power of the water running in the vicinity of his house for washing clothes (in Maramureș), grinding grains - wheat, corn (in Banat, Bucovina). Even if the mills are now simple historical monuments or on their way to total ruin, one can still notice the manner in which they were built so that water is not hindered in its flow downstream. The mill parts are manufactured from wood and stone - raw materials existing in the area. Some stood against the passing of time and still stand proof of their perfect operation.

Another period followed - when hydroelectric power dams were built (Porțile de Fier, Vidraru and Bicaz Hydroelectric Power Stations are renowned for their size and installed capacity). They have quite a high impact upon the environment, but it weighed less against their installed capacity, power efficiency and the fact that the energy generated was not directly pollutant.

The building of these hydroelectric power stations was quite costly in itself, but the energy generated is quite cheap whence their efficiency. The fluctuation in electricity generation, as a result of seasons and draught periods, required that this electricity generating source be supported by other (generally conventional) sources. Hydroelectric power dams are built in areas of special geographical diversity. Unfortunately, these hydroelectric power constructions determine local changes in climate, and have a negative effect upon the fish.

The energy demand determined the adopting of projects called micro hydropower plants (MHPP). Such plants involved a lower cost for their execution, but a lower efficiency as well. The "advantages" consisted in that several of these small power plants using the power of water could be built.

From the information offered by the Ministry of the Environment, there are over 300 such projects all over the country, some of them non-operational. Hidroelectrica has sold 32 such micro hydropower plants and still has another 33 inefficient MHPP's for sale on the market. Although such constructions already exist, some of them non-operational, the number of new projects is quite high. What made investors build new MHPP's? The European funds coming with them were probably the stake. 


\section{Case Study- MHPP - Micro Hydropower Plant on the Nera River}

The herein Chapter will analyze at length the advantages and particularly the disadvantages of such constructions.

After the European Commission launched the infringement procedure for Romania due to the projects on Capra and Buda Rivers in Făgăraș Mountains (MHPP's that destroyed ecosystems and devastated wonderful landscapes), new projects for the building of MHPP's emerge. Among these new projects are the two MHPP's to be built on the Nera River - one of the few rivers in the country still having quality physical-chemical properties.

The advantages of the projects are ostensible. They bring in added value due to their easy arrangement and, as a result, lower execution costs. The development of an area is an argument that accompanies such constructions more than often. Unfortunately, as in the case of the other energy generating solutions from renewable sources, there are clearly no economic advantages for the local community. The advantages are featured in the project beneficiary's incomes (money obtained from selling the electricity by introducing it into the national grid as well as from the green certificates meant to support investments in energy from renewable sources).

The disadvantages of these projects, which may also be extended to other MHPP projects in the country, are:

1. Arrangement of these MHPP is in the close vicinity of protected natural areas:

Site N2000 - ROSCI0226 Semenic - Caraș Keys is 500 m away from the Nera 1 MHPP. Site N2000 downstream ROSCI0375 Nera River between Bozovici and Mocerișis located approximately $17 \mathrm{~km}$ upstream the Nera $2 \mathrm{MHPP}$ (this close distance is within the $20 \mathrm{~km}$ limit recommended by Romania's Energy Strategy ("Avoiding the implementation of projects involving modifications to the watercourse, flow or level within protected natural areas where water has an important role in maintaining habitats/species or within $20 \mathrm{~km}$ upstream such").

2. Such constructions, particularly on Mountain Rivers, affect the fish, mostly salmonidae. Solutions are attempted, such as the building of "steps" for fish on which they could climb upstream (the impact studies have not offered a clear solution to such purpose). The impact study accompanying the projects specifies that not to many or the protected species were noticed upstream and downstream the designed construction. Such an approach decreases any credibility in the accuracy of such study.

Over time, the construction of dams on the Nera River and its tributaries determined a dramatic decrease in the number of sturgeons, which could no longer migrate to reproduce.

3. These projects lead to the irreversible damage of the protected species habitats. Part of the species is specified in the environment impact study, but there are other species, not specified, such as the stone crayfish and the otter. The negative impact is to be noticed in the construction stage of the MHPP's. 
4. The area is renowned for the value of its tree species (the area is in a prime forest areal). Romsilva intervened and specified that no land clearing may be carried out to execute the two water bodies and three MHPP (to be specified that one project describes the building of a MHPP and one water filling and the other project analyzes the erection of two MHPP and a single filling). Without such intervention by Romsilva, the construction works would have sacrificed a forested area (as always, smaller on paper because there is nobody to check the conformity).

5. What is more serious is the fact that Caraș Severin Environmental Protection Agency has not analyzed the cumulated effect of the two projects to block them. Each project was presented as being unique within the areal that was to bear the construction. The environmental impact produced by a construction shall be doubled once it is executed as a continuation of a similar one.

6. Roman era vestiges are in the vicinity of the site for one of the projects, as well as complex-layered archaeological sites, Hallstatt (Basarabi culture) and $3^{\text {rd }}-4^{\text {th }}$ century BC ceramic fragments, but nobody gave a thought to any archaeological survey previous to any intervention.

7. The construction in itself has many shortcomings. The fact that too little water is left for natural servitude makes the lower course of the Nera River dry out during periods with low rainfall. The MHPP's have a problem with their inconstancy in generating electricity - in winter, frazil ice is formed and the plant fails to operate; in spring, floods may occur, which will clog the storage basin and the efficiency is minimized; in summer, draught periods will generate great problems in the good operation of the power plant. The alluvia accumulated in the intake areas, together with vegetal remains, will determine gas emissions.

The story of the two projects has a nice ending, at least for the time being. The assessment procedure also involved a public meeting should take part and express their opinions on the subject. The inhabitants of Prigor Township (administrative locality on the territory of which these MHPP's were to be built) together with environmental protection organizations (WWF being among the most active ones) requested within the public meeting, backed by both scientific and sentimental arguments, that these projects be stopped. The power of their arguments and the wonderful manner in which the community gathered together around the idea of keeping Nera clean convinced the environmental authorities to analyze the impact study reports for the proposed projects with greater professionalism. The facets of reality are multiple. After this small victory, the Nera River is again threatened - this time by the approval issued by the Serbian authorities for the execution of 4 MHPP's on the Jeruga River (a branch of the Nera) (the information being supplied by the Nera Ecological Collaboration Group - GEC NERA). 


\section{Conclusions}

A better cooperation is required between the local authorities, the local community, and the economic agents that want to invest in such projects.

Another conclusion would be that the research and innovation activity in this field should benefit of genuine financial support.

Local strategies must be developed on the possibility obtaining electricity from renewable resources, and local development must be followed up with emphasis on durability. Such strategies must also take into consideration the climate changes that may result in a source becoming more valuable than another in the years to follow.

The use of renewable resources (for generating electricity) for small communities must be stimulated and, what is more, the adopting of an intelligent transmission system must be encouraged.

From the previous studies made, the legislation in the field proved to be too thick and bureaucracy blocks a great part of the projects in the field.

\section{References}

[1] Bratu I., (2015) Premiera negative: primele turbine eoliene din Romania vor fi demontate DeCe NEWS Available at http://www.dcnews.ro/premiera-negativa-primele-turbine-eoliene-din-romania-vor-fidemontate_482133.html

[2] Dawn Stover (2011) The myth of renewable energyAvailable at Bulletin of the Atomic Scientists

[3]Drugă Mariana (2013) Dezvoltarea energiei eoliene în Dobrogea, Available at http://www.sor.ro/img/File/Utile/Analize/1\%20Raport\%20-

\%20dezvoltarea\%20energiei\%20eoliene\%20in\%20Dobrogea.pdf

[4]Kardashev, Nikolai (1985) On the Inevitability and the Possible Structures of Supercivilizations" in "The search for extraterrestrial life: Recent developments; Proceedings of the Symposium, Boston, MA,June 18-21, 1984, p. 497-504.

[5]Kamala Vainy Pillai PhD (2014) Is Renewable Energy Really Green?Available at http://www.forbes.com/sites/realspin/2014/09/24/is-renewable-energy-really-green/\#419fad9e4d8e

[6] Roxana Petrescu (2016) Cel mai verde an: energia produsă de eoliene şi solare a acoperit peste 15\% din consumul de energie, dar investiţiile tind spre zero Ziarul Financiar - EconomieAvailable at www.zf.ro

[7] *** (2016) Sinteza calităţii apelor din România în anul 2015 Administraţia Naţională "Apele Române"

[8] *** Strategia energetică a României pentru perioada 2007-2020 Available at http://www.minind.ro/energie/STRATEGIA_energetica_actualizata.pdf 